\title{
Efektivitas Music Therapy terhadap Pengurangan Nyeri Persalinan: Systematic Review
}

\author{
Nova Avianti Rahayu ${ }^{1}$, Herlin Fitriana Kurnniawati² \\ ${ }^{1}$ Program Studi Magister Kebidanan, Fakultas Ilmu Kesehatan, Universitas ‘Aisyiyah Yogyakarta \\ ${ }^{2}$ Fakultas Ilmu Kesehatan, Universitas 'Aisyiyah Yogyakarta \\ novaavianti05093@gmail.com ${ }^{1}$
}

Diajukan 29 April 2020 Diperbaiki 2 Mei 2020 Diterima 6 Mei 2020

\section{ABSTRAK}

Latar belakang: Nyeri pada persalinan merupakan suatu hal yang normal, tetapi nyeri persalinan juga dapat meningkatan katekolamin. Hal ini dapat mengganggu kontraksi uterus sehingga dapat menyebabkan inersia uteri, partus lama, oksigenasi pada janin tidak adekuat hingga distress janin, serta kematian ibu dan atau janin apabila nyeri persalinan tidak ditangani. Oleh karena itu, penanganan nyeri penting bagi ibu selama persalinan.

Tujuan: Untuk mencari evidence based tentang efektifitas terapi musik terhadap pengurangan nyeri persalinan.

Metode: Ada delapan tahap yang digunakan dalam ulasan ini yaitu mengidentifikasi permasalahan kebidanan, prioritas masalah dan pertanyaan penelitian, framework data primer dan sekunder, identifikasi studi yang relevan, prisma flow diagram, critical appraisal, analisa data dan ekstrasi data. Review ini menggunakan 2 databased dengan jangka waktu dari 2010-2020.

Hasil: Total artikel yang didapatkan adalah 698 artikel, 11 artikel terpilih untuk di-review. Beberapa artikel membandingkan nyeri persalinan pada kelompok terapi musik dan tanpa terapi musik didapatkan hasil terapi musik menjadi salah satu manajemen nyeri non farmakologis yang efektif untuk mengurangi nyeri persalinan.

Kesimpulan: Terapi musik efektif untuk mengurangi nyeri selama persalinan pada fase laten, perlu diteliti lebih lanjut terkait efektifitas dan jenis musik untuk dapat mengurangi nyeri persalinan fase aktif.

Kata Kunci: nyeri persalinan; kecemasan; terapi musik; intervensi musik

\section{ABSTRACT}

Background: Pain in labor is a physiological response, but can cause an increase in catecholamines. That it can cause uterine inertia, prolonged labor, inadequate oxygenation of the fetus to fetal distress, and maternal and fetal death if labor pain is not treated. Pain management is important for mothers during labor.

Objective: To find evidence based on the effectiveness of music therapy for labor pain reduction.

Methods: There are eight stages used in this review, include: identifying problems obstetrics, priority issues and research questions, primary and secondary data framework, the identification of relevant studies, prism flow diagrams, critical appraisal, data analysis and extraction of data. this review uses 2 data based with the period 2010-2020.

Results: Total amount of the article is 698 article and 11 articles selected to be review. Several articles comparing labor pain in the music therapy group and non-music therapy showed that music therapy is one of the effective non-pharmacological pain management to reduce pain during labor.

Conclusion: Music therapy effective for reducing pain during labor in the latent phase, needs to be further investigated regarding the effectiveness and type of music to be able to reduce the pain of active phase labor.

Keywords: labor pain; anxiety; music therapy; music intervention 
PENDAHULUAN

Persalinan merupakan salah satu kejadian yang paling penting dalam kehidupan wanita namun tidak jarang persalinan bisa menimbulkan rasa sakit ataupun stres (Metgud dan Gayathri, 2010). Nyeri persalinan adalah bagian dari proses normal. Namun nyeri persalinan dianggap sebagai aspek yang paling tidak diinginkan dan tidak menyenangkan dari pengalaman persalinan (Labrague et al., 2013).

Nyeri persalinan merupakan kekhawatiran utama bagi setiap ibu hamil karena jika tidak ditangani dengan baik akan berdampak besar pada outcome dari proses kelahiran (Taghinejad et al., 2010). Rasa sakit saat melahirkan bisa menjadi salah satu penyebab stres dan pemilihan kelahiran caesar (Ministério da Saúde, 2017). Rasa nyeri pada persalinan diperlukan untuk mengenali adanya kontraksi uterus selama proses persalinan, tetapi jika ibu merasakan sakit terus menerus bisa menimbulkan akibat patologis. Hal ini dapat mengakibatkan penurunan kontraksi uterus dan memperpanjang durasi persalinan atau partus lama yang dapat membahayakan ibu dan janin (Rahman et al., 2017).

Nyeri persalinan perlu mendapatkan penanganan yang baik dan tidak menimbulkan komplikasi yang dapat mengganggu persalinan (Solehati, 2018). Terdapat beberapa teknik untuk mengurangi nyeri persalinan yaitu farmakologis dan nonfarmakologis (Astuti et al., 2015). Berbagai jenis manajemen nyeri nonfarmakolgis seperti seperti akupunktur, teknik pernapasan dan akupresur, music therapy, terapi pijat dan hydrotherapy. Music therapy, melalui gangguan indera dapat mengurangi konsentrasi ibu terhadap rasa nyeri persalinan sehinga dapat mengurangi kecemasan dan sensasi nyeri (Taghinejad et al., 2010). Terapi musik dapat memberikan efek relaksasi pada tubuh, sehingga berpengaruh pada aliran darah, denyut jantung lebih stabil, dan timbul rasa tenang (Bassano, 2009). Terapi musik tidak dapat menghilangkan nyeri seutuhnya namun terapi musik dapat menurunkan intensitas nyeri dan mengatasi ketidaknyamanan pada ibu selama proses persalinan (Yuliatun, 2008).

Data Survei Penduduk Antar Sensus (SUPAS) tahun 2015, baik AKI maupun AKB menunjukan penurunan yaitu AKI 305/100.000 kelahiran hidup dan AKB 22,23/1000 kelahiran hidup (Direktorat Kesehatan Keluarga, 2016). Penyebab AKI tertinggi pada tahun 2013 masih sama dengan tahun sebelumnya yaitu perdarahan $(30,3 \%)$, hipertensi $(27,1 \%)$, infeksi $(7,3 \%)$, partus lama $(1,8 \%)$ dan abortus $(1,3 \%)$

Partus lama (Prolonged labor) menjadi salah satu diagnosis potensial jika nyeri persalinan tidak ditangani dengan baik. Nyeri persalinan perlu mendapatkan penanganan yang baik dan tidak menimbulkan komplikasi yang dapat mengganggu persalinan. Oleh karena itu, perlu dilakukan sistematic review tentang efektifitas music therapy terhadap pengurangan nyeri persalinan.

Tujuan sistematic review ini adalah mencari evidence based tentang efektifitas terapi musik terhadap pengurangan nyeri persalinan. Diharapkan dapat menjadi suatu evidence yang didapat dari penelitian-penelitian yang sudah dilakukan baik di Asia ataupun negara lainnya, sehingga bisa menjadi referensi dalam penerapan penanganan manajemen nyeri persalinan di Indonesia.

\section{METODE}

\section{Identifikasi masalah}

Langkah utama dalam penyusunan systematic review ini adalah dengan mengidentifikasi permasalahan yang terjadi di masyarakat. Rasa sakit yang berkepanjangan selama persalinan menjadi penyebab ibu untuk memilih kelahiran caesar. Penelitian menunjukkan bahwa bayi yang dilahirkan dengan seksio 
Efektivitas Music Therapy Terhadap Pengurangan Nyeri Persalinan...

sesarea berbeda dengan bayi yang lahir alami atau per vaginam. Seksio sesaria juga dapat menyebabkan cedera substansial pada ibu (Gayiti et al., 2015). Selain itu, nyeri dan stres dalam persalinan dapat menyebabkan partus lama dan peningkatan katekolamin (Taghavi et al., 2015). Music therapy banyak digunakan untuk meningkatkan status kesehatan, mengurangi nyeri persalinan, mengurangi stres, dan mengurangi kecemasan (Hosseini et al., 2013).

\section{Pencarian artikel}

Pencarian artikel pada 2 databases yaitu Pubmed dan ProQuest serta menggunakan sumber lain berupa reference list. Reference list didapatkan dari daftar referensi atau daftar pustaka pada penelitian lain yang sesuai dengan topik ataupun website resmi dari lembaga dunia maupun lembaga nasional seperti WHO dan web kementerian kesehatan. Dari 2 databases tersebut didapatkan artikel sebanyak 1216, kemudian beberapa artikel yang sama akan dihapus sehingga didapatkan 698 artikel. Kemudian dilakukan penyaringan artikel lebih lanjut untuk mencari referensi yang tepat dan lengkap mengenai efektifitas music therapy terdahap pengurangan nyeri persalinan dan didapatkan 11 artikel yang akan digunakan untuk Systematic Review. Pencarian artikel menggunakan kata kunci utama yaitu "Music Therapy" dan "Labor pain". Pemilihan artikel dilakukan dengan menggunakan/mengacu pada panduan PRISMA (Moher et al., 2009).

Artikel tersebut dibatasi tahun terbit atau publish 10 tahun terakhir, artikel menggunakan bahasa inggris, Negara penelitian bukan merupakan Negara dengan konflik.

Penulis melakukan critical appraisal menggunakan checklist dari Joanna Briggs Institute (Joanna Briggs Institute, 2017). Setelah melakukan critical appraisal terpilih 11 artikel yang berdasarkan penilaian penulis memiliki kualitas yang bagus dan sesuai dengan topik.

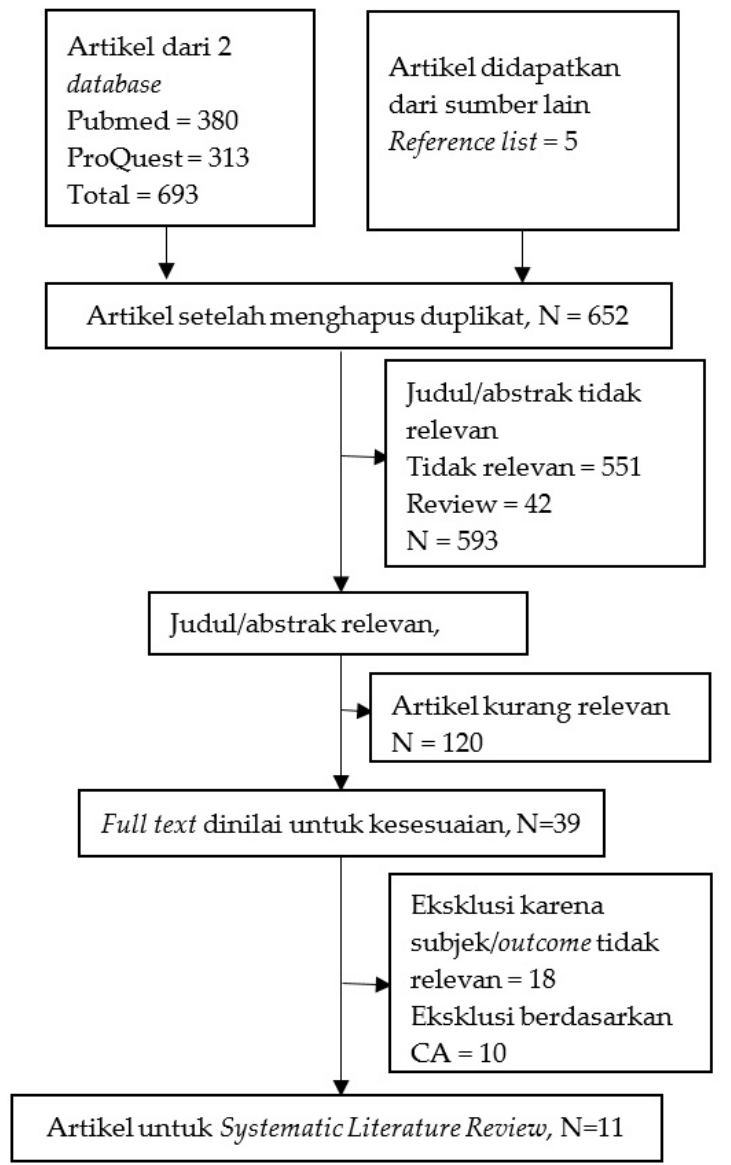

Gambar 1. Proses pemilihan artikel

\section{Ekstraksi Data}

Langkah selanjutnya adalah melakukan ekstraksi data dari artikel yang telah terpilih, ekstraksi data dilakukan untuk menggolongkan atau mengkategorikan artikel dan membuat gambaran besar mengenai isi artikel. Data dari 11 artikel diekstraksi untuk memasukkan kriteria kunci seperti judul, penulis, tahun penerbitan artikel, lokasi penelitian, tujuan penelitian, metodologi, populasi penelitian, dan hasil atau kesimpulan yang signifikan. Penulis secara independen mencatat informasi dan kemudian membandingkan data yang di ekstrak. Artikel yang telah ditemukan, diidentifikasi dan disaring oleh penulis kemudian dinilai kelayakan studi dan mengekstraksi data ke dalam tabel dengan judul yang telah ditentukan. 
Tabel 1. Ekstraksi Data

\begin{tabular}{|c|c|c|c|c|c|c|}
\hline No & $\begin{array}{c}\text { Judul/Penulis/ } \\
\text { Tahun }\end{array}$ & Negara & Tujuan & $\begin{array}{c}\text { Jenis } \\
\text { Penelitian }\end{array}$ & Pengumpulan Data & Partisipan/ ukuran sampel \\
\hline 1 & $\begin{array}{l}\text { Comparison } \\
\text { between massage } \\
\text { and music therapies } \\
\text { to relieve the } \\
\text { severity of labor } \\
\text { pain (Taghinejad et } \\
\text { al., 2010) }\end{array}$ & Iran & $\begin{array}{l}\text { Untuk } \\
\text { membandingkan } \\
\text { efek terapi pijat } \\
\text { dan terapi musik } \\
\text { pada tingkat } \\
\text { nyeri persalinan } \\
\text { di provinsi Ilam } \\
\text { Iran barat. }\end{array}$ & RCT & $\begin{array}{l}\text { Percobaan klinis acak ini } \\
\text { dilakukan pada tahun } 2007 \text {. } \\
\text { Partisipan adalah primipara } \\
\text { berusia antara } 20-30 \text { tahun } \\
\text { dengan pelebaran serviks kurang } \\
\text { dari } 4 \mathrm{~cm} \text {, usia kehamilan } 37-42 \\
\text { minggu dan presentasi kepala } \\
\text { dan perkiraan berat lahir normal. }\end{array}$ & $\begin{array}{l}\text { 101 ibu primigravida yang Ibu dalam kelompok terapi } \\
\text { dirawat di rumah sakit pijat memiliki tingkat rasa } \\
\text { untuk persalinan sakit yang lebih rendah } \\
\text { pervaginam kemudian dibandingkan } \\
\text { dikelompokkan dengan } \\
\text { acak menjadi dua kelompok terapi musik }(\mathrm{p}= \\
\text { kelompok yaitu kelompok 0,009). } \\
\text { pijat }(n=51) \text { dan kelmpok } \\
\text { musik }(n=50)\end{array}$ \\
\hline 2 & $\begin{array}{l}\text { Complementary and } \\
\text { alternative therapies } \\
\text { to relieve labor pain: } \\
\text { A comparative } \\
\text { study between } \\
\text { music therapy and } \\
\text { Hoku point ice } \\
\text { Massage } \\
\text { (Dehcheshmeh } \\
\text { dan Rafiei, 2015) }\end{array}$ & Iran & $\begin{array}{l}\text { Untuk } \\
\text { membandingkan } \\
\text { efektifitas dari } \\
\text { manajemen nyeri } \\
\text { persalinan non } \\
\text { farmakologis } \\
\text { yaitu "music } \\
\text { therapy" dan } \\
\text { "Hoku pol } \\
\text { pijat titik es" }\end{array}$ & $\mathrm{RCT}$ & $\begin{array}{l}\text { Penelitian dilakukan pada } \\
\text { September } 2013 \text { sampai Juni } \\
2014.90 \text { ibu primipara secara acak } \\
\text { dibagi menjadi } 3 \text { kelompok: } \\
\text { kelompok "A" menerima music } \\
\text { therapy, kelompok "B" menerima } \\
\text { pijatan es titik Hoku, dan } \\
\text { kelompok "C" menerima } \\
\text { perawatan persalinan biasa. } \\
\text { pada dilatasi serviks 4cm, 6cm, } \\
\text { dan 8cm), dilakukan penilaian } \\
\text { intervensi sebelum dan sesudah } \\
\text { diberikan terapi. }\end{array}$ & $\begin{array}{l}\text { Sampel pada penelitian ini Pada awal fase aktif, skor } \\
\text { yaitu 90 ibu hamil VAS rata-rata adalah } 5,58 \pm \\
\text { primipara yang dirawat di } 1,29,5,42 \pm 1,31 \text {, dan } 6,13 \pm \\
\text { rumah sakit pemerintah di } 1,37 \text { pada wanita dalam } \\
\text { Shahrekord, barat daya kelompok "A," "B," dan "C," } \\
\text { Iran. } \\
\text { masing-masing (p> 0,05). } \\
\text { Setelah intervensi, skor nyeri } \\
\text { rata-rata secara signifikan } \\
\text { lebih rendah pada kelompok } \\
\text { "A" dan "B" daripada di } \\
\text { kelompok "C" wanita (p } \\
<0,05) .\end{array}$ \\
\hline 3 & $\begin{array}{l}\text { A Randomized } \\
\text { Controlled Trial of } \\
\text { Music Use During } \\
\text { Epidural Catheter } \\
\text { Placementr on } \\
\text { Laboring Parturient } \\
\text { Anxiety, Pain, and } \\
\text { Satisfaction } \\
\text { (Drzymalski et al., } \\
\text { 2017) }\end{array}$ & USA & $\begin{array}{l}\text { Untuk } \\
\text { menentukan efek } \\
\text { penggunaan } \\
\text { terapi musik } \\
\text { terhadap } \\
\text { persalinan } \\
\text { selama } \\
\text { penempatan } \\
\text { kateter epidural }\end{array}$ & RCT & $\begin{array}{l}\text { Uji coba acak dilakukan pada ibu } \\
\text { melahirkan yang menjalani } \\
\text { penempatan kateter epidural } \\
\text { dengan atau tanpa musik. Hasil } \\
\text { utama adalah } 3 \text { ukuran } \\
\text { kecemasan. Hasil sekunder } \\
\text { termasuk nyeri, kepuasan } \\
\text { pasien, parameter hemodinamik, } \\
\text { parameter kebidanan, hasil } \\
\text { neonatal, dan kecemasan } \\
\text { penyedia anestesi. }\end{array}$ & 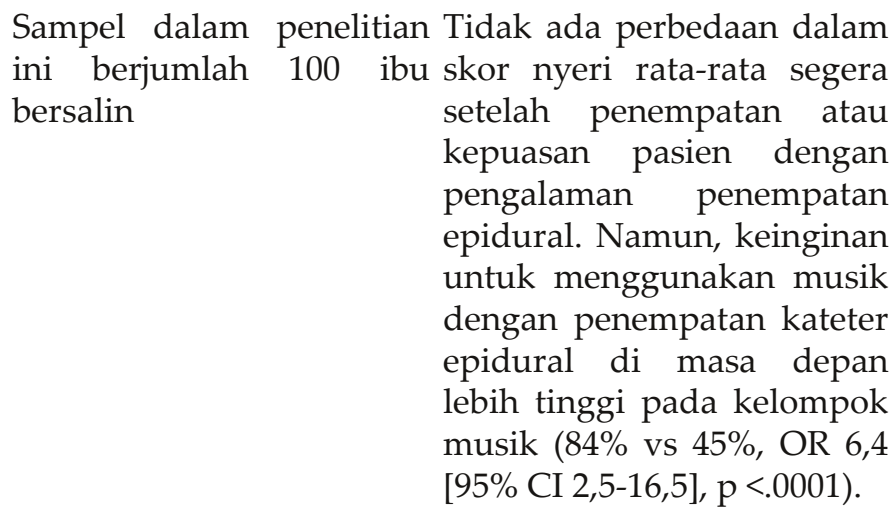 \\
\hline
\end{tabular}


Tabel 1. Ekstraksi Data (Lanjutan)

\begin{tabular}{|c|c|c|c|c|}
\hline 4 & $\begin{array}{l}\text { Effect of music Turkey } \\
\text { therapy during } \\
\text { vaginal delivery on } \\
\text { postpartum pain } \\
\text { relief and mental } \\
\text { health (Simavli, } \\
\text { Kaygusuz, et al., } \\
\text { 2014) }\end{array}$ & $\begin{array}{l}\text { Untuk } \\
\text { mengevaluasi } \\
\text { efek music } \\
\text { therapy pada } \\
\text { nyeri post } \\
\text { partum, tingkat } \\
\text { kecemasan, } \\
\text { kepuasan dan } \\
\text { tingkat depresi } \\
\text { postpartum dini. }\end{array}$ & RCT & 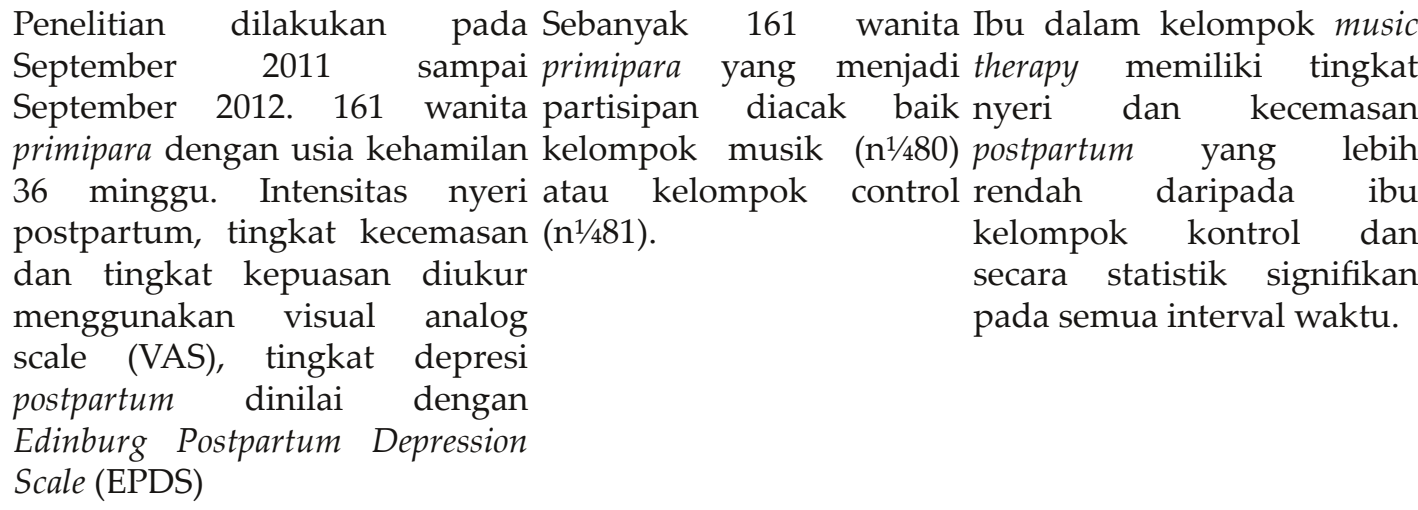 \\
\hline 5 & $\begin{array}{l}\text { Effects of music Taiwan } \\
\text { therapy on labour } \\
\text { pain and anxiety in } \\
\text { Taiwanese first-time } \\
\text { mothers (Liu et al., } \\
\text { 2010) }\end{array}$ & $\begin{array}{lr}\text { Tujuan } & \text { dari } \\
\text { penelitian } & \text { ini } \\
\text { adalah untuk } \\
\text { menyelidiki efek } \\
\text { terapi musik } \\
\text { pada tingkat } \\
\text { nyeri } \\
\text { kecemasan } \\
\text { selama } \\
\text { persalinan. }\end{array}$ & $\begin{array}{l}\text { Quasi } \\
\text { experimental }\end{array}$ & 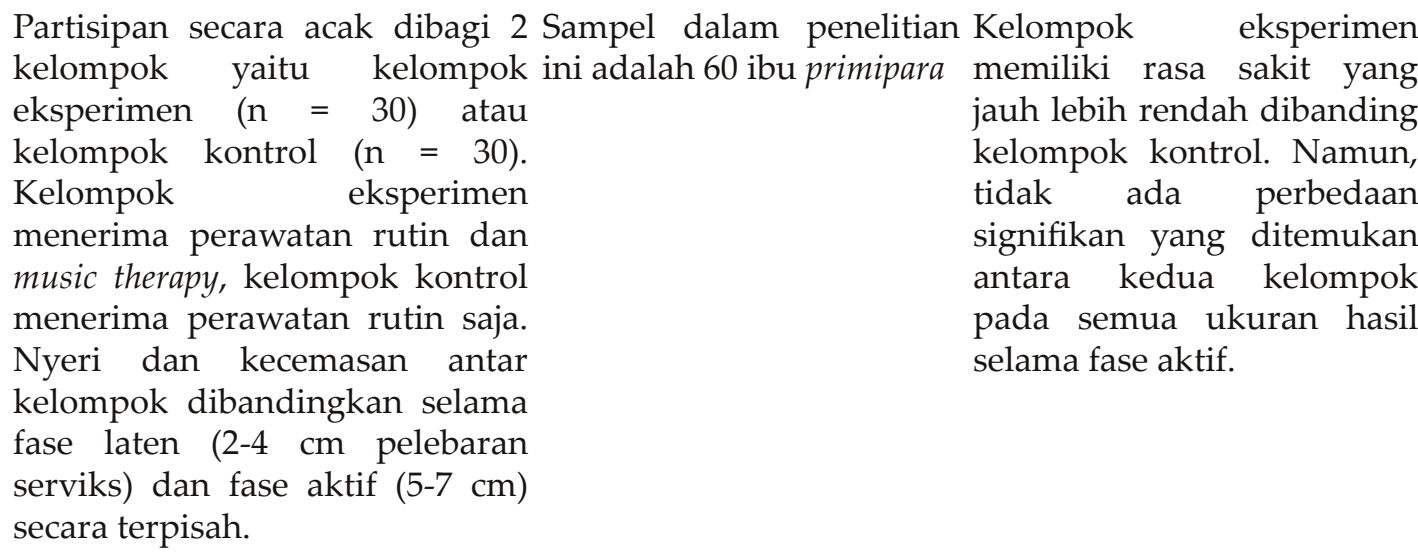 \\
\hline 6 & $\begin{array}{l}\text { The effect of music Turkey } \\
\text { on pain and anxiety } \\
\text { of women during } \\
\text { labour on first time } \\
\text { pregnancy: A study } \\
\text { from Turkey } \\
\text { (Gokyildiz Surucu } \\
\text { et al., 2018) }\end{array}$ & $\begin{array}{l}\text { Untuk } \\
\text { menganalisis } \\
\text { pengaruh musik } \\
\text { pada nyeri dan } \\
\text { kecemasan yang } \\
\text { dirasakan oleh } \\
\text { wanita dalam } \\
\text { persalinan } \\
\text { selama } \\
\text { kehamilan } \\
\text { pertama mereka. }\end{array}$ & $\begin{array}{l}\text { Quasi } \\
\text { experimental }\end{array}$ & $\begin{array}{l}\text { Wanita hamil dalam kelompok Sampel terdiri dari wanita Rasa sakit secara statistik } \\
\text { eksperimen berkembang ke fase hamil sehat yang lebih sedikit pada kelompok } \\
\text { aktif persalinan, mereka diminta memenuhi } \\
\text { untuk mendengarkan musik penelitian. Penelitian ini wanita dalam persalinan } \\
\text { dalam mode Acemasiran dengan dilakukan dengan } 50 \text { sama untuk kelompok } \\
\text { penyumbat telinga selama } 3 \text { jam wanita primipara }(25 \text { eksperimen dan kontrol. } \\
\text { (20 menit mendengarkan dengan untuk kelompok Setelah latihan, skor rata- } \\
\text { istirahat } 10 \text { menit). } \\
\text { eksperimen, 25 untuk rata kecemasan lebih rendah } \\
\text { kelompok kontrol). } \\
\text { pada kelompok eksperimen } \\
\text { dan korelasinya signifikan } \\
\text { secara statistik. }\end{array}$ \\
\hline
\end{tabular}




\begin{tabular}{|c|c|c|c|c|}
\hline 7 & $\begin{array}{l}\text { Effect of Music on USA } \\
\text { Labor Pain Relief, } \\
\text { Anxiety Level and } \\
\text { Postpartum } \\
\text { Analgesic } \\
\text { Requirement: A } \\
\text { Randomized } \\
\text { Controlled Clinical } \\
\text { Trial (Simavli, } \\
\text { Gumus, et al., } \\
\text { 2014) }\end{array}$ & $\begin{array}{l}\text { Untuk } \\
\text { mengevaluasi } \\
\text { efek terapi } \\
\text { musik pada } \\
\text { nyeri persalinan } \\
\text { dan kecemasan, } \\
\text { hemodinamik } \\
\text { ibu, parameter } \\
\text { janin-neonatal } \\
\text { dan kebutuhan } \\
\text { analgesik } \\
\text { postpartum pada } \\
\text { ibu primipara. }\end{array}$ & $\mathrm{RCT}$ & 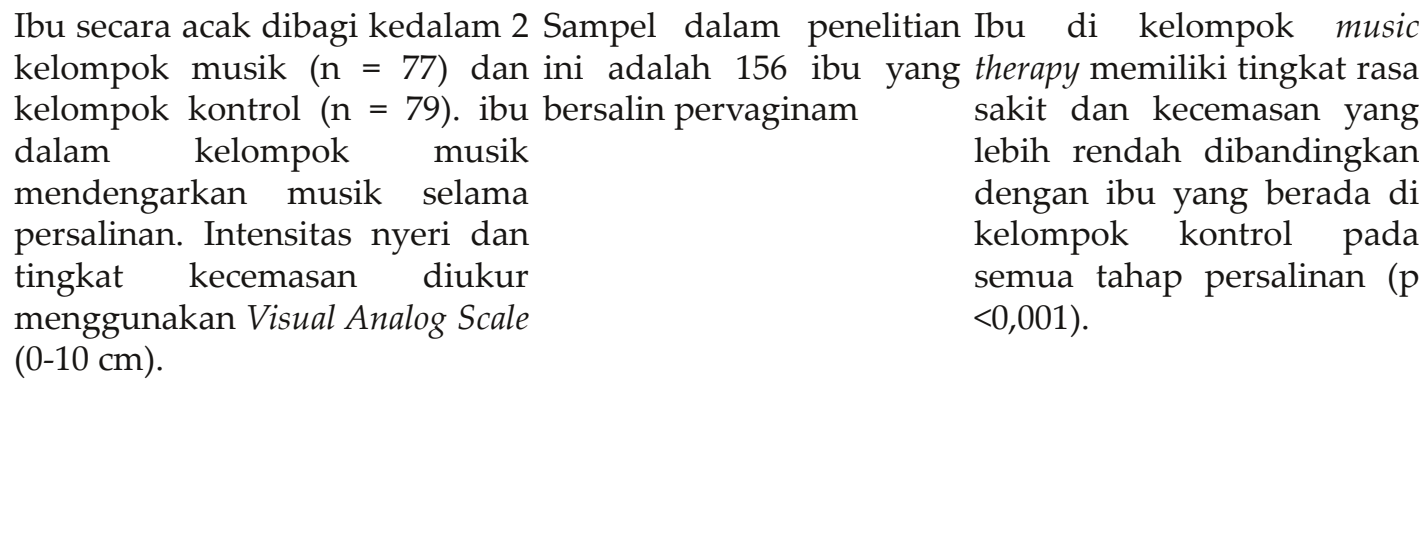 \\
\hline 8 & $\begin{array}{l}\text { Investigating the Iran } \\
\text { effect of music on } \\
\text { labor pain and } \\
\text { progress in the } \\
\text { active stage of first } \\
\text { labor (Hosseini et } \\
\text { al., 2013) }\end{array}$ & $\begin{array}{l}\text { Untuk } \\
\text { menganalisis } \\
\text { efek dari music } \\
\text { therapy pada } \\
\text { nyeri persalinan } \\
\text { dan kemajuan } \\
\text { persalinan pada } \\
\text { ibu primipara. }\end{array}$ & $\begin{array}{l}\text { Quasi } \\
\text { experimental }\end{array}$ & $\begin{array}{l}\text { Penelitian ini dilakukan dengan Sampelnya adalah } 30 \text { ibu Hasil analisis menunjukkan } \\
\text { bentuk pre-test dan post-test bersalin yang dipilih terapi musik berpengaruh } \\
\text { design. Populasinya adalah ibu secara sukarela dan terhadap penurunan rasa } \\
\text { bersalin yang berusia 20-30 dimasukkan ke dalam dua sakit pada kelompok } \\
\text { tahun, tinggal di tempat tinggal eksperimen dan kelompok eksperimental dibandingkan } \\
\text { perkotaan. } \\
\text { control. }\end{array}$ \\
\hline 9 & $\begin{array}{l}\text { Use of Music Filipina } \\
\text { Intervention for } \\
\text { Reducing Anxiety } \\
\text { and Promoting } \\
\text { Satisfaction in } \\
\text { First-Time Filipino } \\
\text { Fathers (Labrague } \\
\text { dan McEnroe- } \\
\text { Petitte, 2016) }\end{array}$ & $\begin{array}{l}\text { Bertujuan untuk } \\
\text { menentukan efek } \\
\text { terapi musik dan } \\
\text { kepuasan ayah } \\
\text { di Filipina saat } \\
\text { pertama kali } \\
\text { mendampingi } \\
\text { persalinan. }\end{array}$ & $\begin{array}{l}\text { Quasi } \\
\text { experimental }\end{array}$ & 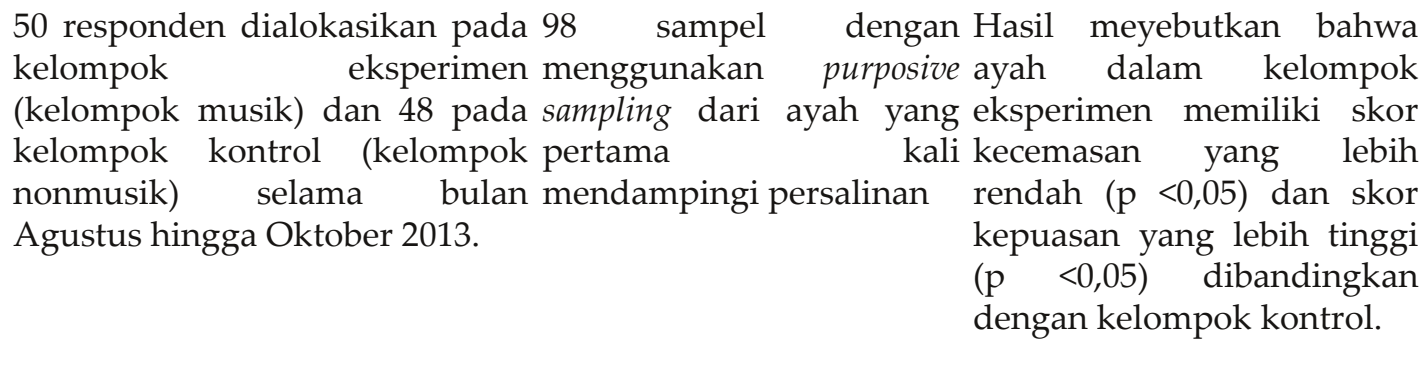 \\
\hline
\end{tabular}


Tabel 1. Ekstraksi Data (Lanjutan)

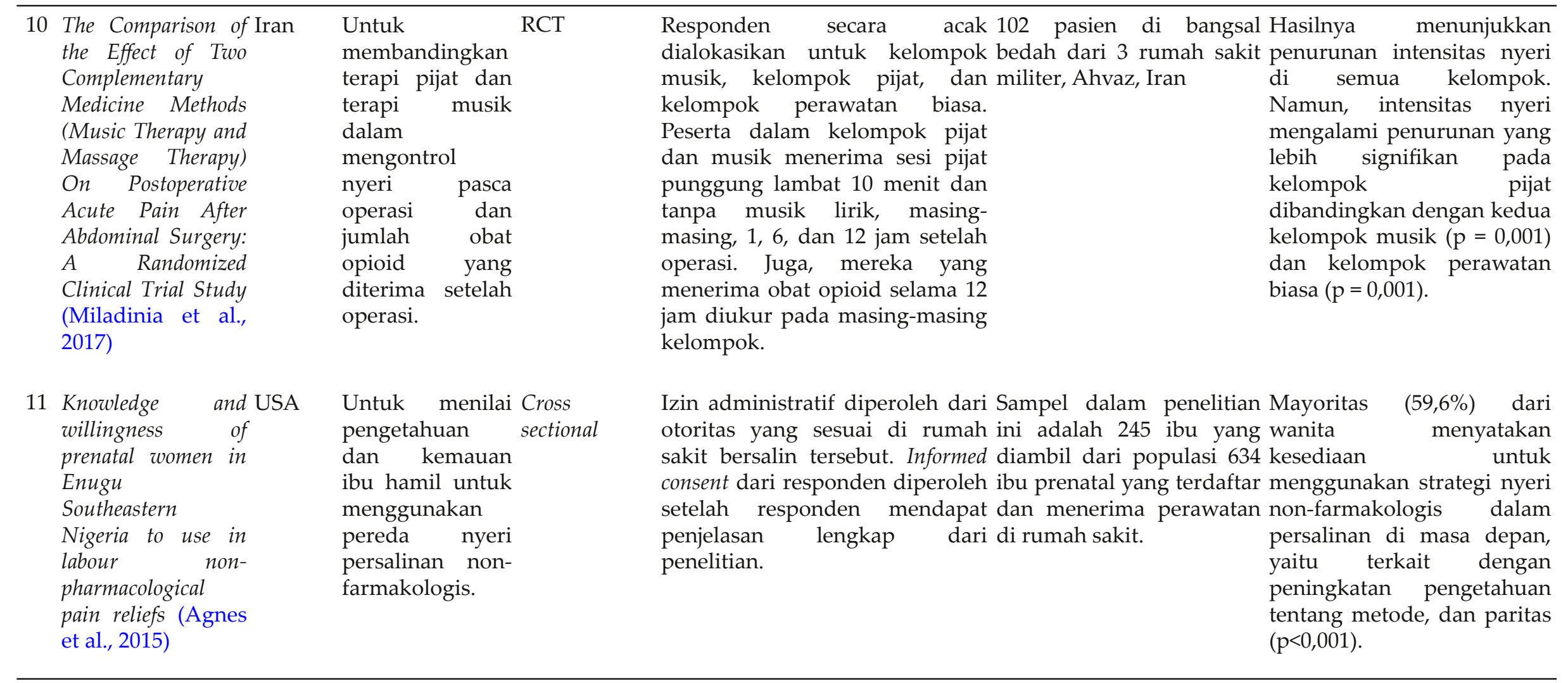


Efektivitas Music Therapy Terhadap Pengurangan Nyeri Persalinan...

HASIL DAN PEMBAHASAN

Perbandingan Tingkat Nyeri Ibu yang

Bersalin dengan Music therapy dan Ibu

Bersalin Normal

Berdasarkan hasil penelitian yang dilakukan oleh Dehcheshmeh et al. (2015) yang membandingkan intensitas nyeri persalinan pada 3 kelompok, didapatkan hasil bahwa wanita dalam kelompok B "Hoku Icemassage" mengalami tingkat rasa sakit yang secara signifikan lebih rendah daripada wanita dengan kelompok $\mathrm{C}$ "Bersalin Normal" $(\mathrm{p}<0,05)$ (Dehcheshmeh dan Rafiei, 2015). Penelitian Marolik dan Charles di AS pada tahun 1996 telah menunjukkan bahwa wanita yang telah menjalani terapi musik selama persalinan dan melahirkan, telah melaporkan lebih sedikit stres dan rasa sakit. Studi telah menunjukkan bahwa musik yang tenang akan menyebabkan pengurangan pasca operasi kecemasan dan rasa sakit (Hosseini et al., 2013).

Penelitian yang dilakukan oleh Taghinejad et al. (2010), dimana 101 wanita hamil dibedakan ke dalam dua kelompok yaitu terapi pijat (n $1 / 4$ 51) dan terapi musik (n $1 / 4$ 50). Untuk mengukur intensitas nyeri, menggunakan VAS (Visual Analog Scale). Kedua terapi pijat dan terapi musik efektif dalam menghilangkan nyeri persalinan. Ibu dalam kelompok terapi pijat memiliki tingkat rasa sakit yang lebih rendah dibandingkan dengan mereka yang dalam kelompok terapi musik $(p=0,009)$. Perbedaan signifikan diamati antara kedua kelompok dalam hal intensitas nyeri setelah intervensi $(p=0,01)$ (Taghinejad et al., 2010).

Ibu dalam kelompok music therapy memiliki tingkat nyeri dan kecemasan postpartum yang lebih rendah daripada ibu kelompok kontrol dan secara statistik signifikan pada semua interval waktu (Simavli, Gumus, et al., 2014). Kelompok eksperimen (Music therapy) memiliki rasa sakit yang jauh lebih rendah dibanding kelompok kontrol. Namun, tidak ada perbedaan signifikan yang ditemukan antara kedua kelompok pada semua ukuran hasil selama fase aktif (Liu et al., 2010).

Rasa sakit secara statistik lebih sedikit pada kelompok eksperimen. Skor kecemasan wanita dalam persalinan sama untuk kelompok eksperimen dan kontrol. Setelah latihan, skor rata-rata kecemasan lebih rendah pada kelompok eksperimen dan korelasinya signifikan secara statistik (Gokyildiz Surucu et al., 2018). Ibu di kelompok music therapy memiliki tingkat rasa sakit dan kecemasan yang lebih rendah dibandingkan dengan ibu yang berada di kelompok kontrol pada semua tahap persalinan $(\mathrm{p}<0,001) \quad$ (Simavli, Gumus, et al., 2014). Hasil analisis menunjukkan terapi musik berpengaruh terhadap penurunan rasa sakit pada kelompok eksperimental dibandingkan dengan kelompok kontrol (Hosseini et al., 2013).

Hasil meyebutkan bahwa ayah dalam kelompok eksperimen memiliki skor kecemasan yang lebih rendah $(\mathrm{p}<0,05)$ dan skor kepuasan yang lebih tinggi $(p<0,05)$ dibandingkan dengan kelompok kontrol (Labrague dan McEnroe-Petitte, 2016).

Hasilnya menunjukkan penurunan intensitas nyeri di semua kelompok. Namun, intensitas nyeri mengalami penurunan yang lebih signifikan pada kelompok pijat dibandingkan dengan kedua kelompok musik $(p=0,001)$ dan kelompok perawatan biasa $(p=0,001)$ (Miladinia et al., 2017). Mayoritas (59,6\%) dari wanita menyatakan kesediaan untuk menggunakan strategi nyeri nonfarmakologis dalam persalinan di masa depan, yaitu terkait dengan peningkatan pengetahuan tentang metode, dan paritas ( $p<0,001)$ (Agnes et al., 2015).

Hasil review menunjukan bahwa musik mampu mengurangi tingkat rasa sakit dan efektif untuk mendorong relaksasi dan mengurangi kecemasan para wanita dalam kelompok eksperimen selama fase laten persalinan. Namun, skor 
Efektivitas Music Therapy Terhadap Pengurangan Nyeri Persalinan...

untuk variabel nyeri dan kecemasan selama fase aktif tidak berbeda secara signifikan antara kelompok eksperimen dan kelompok kontrol. Hal ini sejalan dengan penelitian Guzzetta (1989) bahwa musik dapat meningkatkan relaksasi dan mengurangi ketegangan otot, yang dapat meningkatkan aliran darah perifer serta suhu kulit. Pereda nyeri selama persalinan meningkatkan kepuasan ibu hamil dari pengalaman melahirkan (Dehcheshmeh \& Rafiei, 2015; Guzzetta CE, 1989).

Nyeri pada persalinan merupakan ketidaknyamanan terhadap respon fisiologis, yaitu proses penerimaan impuls nyeri menuju syaraf pusat dan respon psikis yang meliputi rekognosi sensasi, interpretasi rasa nyeri, dan respon terhadap hasil interpretasi nyeri (Bobak et al., 2004; Solehati, 2018). Selain itu, nyeri juga menyebabkan perubahan afektif berupa peningkatan kecemasan disertai penyempitan lapang perseptual, mengerang, menangis, dan ketegangan otot yang sangat pada seluruh tubuh (Bobak et al., 2004).

Nyeri persalinan dapat menyebabkan hiperventilasi, sehingga meningkatkan kebutuhan oksigen dan tekanan darah serta menurunkan motilitas usus dan vesika urinaria. Kondisi tersebut akan merangsang peningkatan katekolamin yang dapat mengganggu kontraksi uterus, sehingga dapat menyebabkan inersia uteri, partus lama, oksigenasi bayi tidak adekuat hingga distress janin, serta kematian ibu dan atau janin apabila nyeri persalinan tidak ditangani (Llewllyn, 2001; Sastrawinata, 2004; Solehati et al., 2018).

Musik mampu mengurangi tingkat rasa sakit dan efektif untuk mendorong relaksasi dan mengurangi kecemasan para wanita selama persalinan. Namun, skor untuk variabel nyeri dan kecemasan selama fase aktif tidak berbeda secara signifikan antara kelompok eksperimen dan kelompok kontrol. Musik banyak digunakan untuk meningkatkan status kesehatan, mengurangi stres, membuat pasien jauh dari gejala yang tidak menyenangkan dan mengurangi kecemasan (Oyetunde dan Ojerinde, 2013).

Menurut teori kontrol gerbang, musik dapat memberikan gangguan dari rasa sakit atau mengurangi rasa sakit dengan mengurangi transfer sinyal ke thalamus dan sistem pengaktif reticular. Musik tampaknya memiliki banyak fungsi dalam pengurangan rasa sakit, termasuk fokus, mengalihkan perhatian dan merangsang respons kesenangan (Richards et al., 2007). Musik meredakan rasa sakit dan kegelisahan dengan merangsang kesenangan, mengalihkan konsentrasi dan menyediakan jembatan untuk meditasi (Good et al., 2005).

Musik dengan sifat lambat, santai dan menenangkan dengan sedikit variasi dalam tempo atau volume sangat membantu bagi wanita melahirkan terutama pada tahap awal persalinan unutuk mengurangi nyeri persalinan. Musik ringan dapat memberikan efek ketenangan melalui interaksi dengan sistem saraf otonom. Karena semua orang tidak cenderung memilih satu gaya musik karena perbedaan usia dan budaya, pemilihan musik oleh pasien akan sangat penting dalam music therapy. Musik yang tenang tanpa irama dan tempo yang cepat, dengan ritme yang lambat dan nada level yang lebih tepat untuk terapi musik. Penelitian telah menunjukkan bahwa mendengarkan musik selama persalinan meningkatkan resistensi terhadap rasa sakit, memperkuat suasana hati dan menyebabkan parturient untuk bernafas secara teratur dan dalam, itu juga dapat memiliki efek pada kepribadian bayi yang baru lahir (Hosseini et al., 2013).

Selama persalinan, musik dapat berfungsi dengan memfokuskan perhatian atau gangguan, untuk respon kesenangan, sebagai stimulus untuk relaksasi (Liu et al., 2010). Mendengarkan musik selama persalinan memiliki dampak positif pada nyeri dan kecemasan persalinan, 
Efektivitas Music Therapy Terhadap Pengurangan Nyeri Persalinan...

parameter ibu-janin dan kebutuhan analgesik (Simavli, Kaygusuz, et al., 2014). Ketegangan emosional mempengaruhi lamanya persalinan dengan meningkatkan katekolamin dan kortisol, dan tingginya kadar epinefrin plasma dapat dilihat pada wanita hamil yang memiliki tingkat kecemasan tertinggi, wanita ini menderita akibat penurunan aktivitas uterus dan berkepanjangan (Levett et al., 2016).

Musik efektif untuk mengurangi nyeri persalinan selama fase laten namun belum ada cukup bukti untuk mendukung efek musik pada nyeri persalinan selama fase aktif. Jenis musik dalam penelitian ini tidak efektif diterapkan dalam fase aktif persalinan ketika kontraksi lebih intens dan lebih menyakitkan (Good et al., 2005).

Selama persalinan, ibu akan mengalami nyeri dengan intensitas tinggi akibat adanya kontraksi uterus. Efek dari nyeri tersebut dapat menimbulkan dtres dan akan mempengaruhi kondisi ibu dan janin. Oleh karena itu, ibu bersalin sangat membutuhkan dukungan, empati dan rasa nyaman selama persalinan yang bisa didapatkan dari tenaga kesehatan maupun sumi sebagai pendamping persalinan. Kualitas dukungan yang diberikan juga akan mempengaruhi kepuasan ibu selama proses kelahiran (Oyetunde dan Ojerinde, 2013).

Stres menghasilkan respons fisiologis dan biokimiawi yang khas bagi individu sehubungan dengan durasi, intensitas, dan efek keseluruhannya, dan dapat menyebabkan hipertensi dan peningkatan denyut jantung dengan mengaktifkan poros hormon hipotalamus-hipofisisadrenal dan sistem saraf simpatik, dan dengan meningkatkan kardiovaskular. Fungsi sistem dan mencegah ketenangan seseorang, itu bisa memiliki efek negatif pada kesehatan seseorang dan menjadi risiko baginya, stres yang merupakan penyakit yang lazim di antara pasien yang dirawat di rumah sakit adalah keadaan emosional yang digambarkan oleh ketegangan, kemarahan, kekhawatiran, ketakutan, dan peningkatan aktivitas sistem saraf otonom, aksis hormon hipotalamus-hipofisis-adrenal, peningkatan denyut jantung, hipertensi dan curah jantung dengan efek mental dan fisik (Hosseini et al., 2013).

\section{KETERBATASAN PENELITIAN}

Artikel ini mereview 11 artikel dari berbagai negara maju dan negara berkembang, sehingga hasil review ini masih bersifat universal dan belum spesifik untuk diterapkan di Indonesia dikarenakan karakteristik dari berbagai responden yang berbeda.

\section{KESIMPULAN}

Terapi musik efektif untuk mengurangi nyeri selama persalinan pada fase laten, perlu diteliti lebih lanjut terkait efektifitas dan jenis musik untuk dapat mengurangi nyeri persalinan fase aktif. Perbandingan tingkat nyeri ibu dengan terapi musik lebih rendah dibandingkan dengan ibu bersalin normal tanpa intervensi.

\section{DAFTAR PUSTAKA}

Agnes, A., Euphemia, A., Eunice, N., Anthonia, C., \& Yolanda, O. (2015). Knowledge and willingness of prenatal women in Enugu Southeastern Nigeria to use in labour non-pharmacological pain reliefs. African Health Sciences, 15(2), 568. https://doi.org/10.4314/ahs.v15i2.32

Astuti, I. W., Utami, P. A. S., Widyanthari, D. M., \& Devayanti, N. Y. (2015). Pengaruh Hydrotheraphy Terhadap Nyeri Persalinan Kala I Fase Aktif Di Denpasar. Seminar Nasional Sains Dan Teknolog (Senastek), 1-6. https:// repositori.unud.ac.id/protected/ storage/upload/repositori/ 84870d472437d9563d83f777c7e37621.p $\mathrm{df}$

Bassano, M. (2009). Terapi Musik dan Warna. Rumpun. 
Bobak, Lowdermilk, \& Jensen. (2004). Buku Ajar Keperawatan Maternitas/ Maternity Nursing (Edisi 4). EGC.

Dehcheshmeh, F. S., \& Rafiei, H. (2015). Complementary and alternative therapies to relieve labor pain: A comparative study between music therapy and Hoku point ice massage. Complementary Therapies in Clinical Practice, 21(4), 229-232. https://doi.org/ 10.1016/j.ctcp.2015.09.002

Direktorat Kesehatan Keluarga. (2016). Laporan Tahunan Direktorat Kesehatan Keluarga Tahun 2016. Direktorat Kesehatan Keluarga.

Drzymalski, D. M., Tsen, L. C., Palanisamy, A., Zhou, J., Huang, C.C., \& Kodali, B. S. (2017). A Randomized Controlled Trial of Music Use During Epidural Catheter Placement on Laboring Parturient Anxiety, Pain, and Satisfaction. Anesthesia \& Analgesia, 124(2), 542547. https://doi.org/10.1213/ANE. 0000000000001656

Gayiti, M.-R.-Y., Li, X.-Y., Zulifeiya, A. K., Huan, Y., \& Zhao, T.-N. (2015). Comparison of the effects of water and traditional delivery on birthing women and newborns. European Review for Medical and Pharmacological Sciences, 19(9), 1554-1558. http:// www.ncbi.nlm.nih.gov/pubmed/ 26004591

Gokyildiz Surucu, S., Ozturk, M., Avcibay Vurgec, B., Alan, S., \& Akbas, M. (2018). The effect of music on pain and anxiety of women during labour on first time pregnancy: A study from Turkey. Complementary Therapies in Clinical Practice, 30, 96-102. https:// doi.org/10.1016/j.ctcp.2017.12.015

Good, M., Anderson, G. C., Ahn, S., Cong, X., \& Stanton-Hicks, M. (2005). Relaxation and music reduce pain following intestinal surgery. Research in Nursing \& Health, 28(3), 240-251. https://doi.org/10.1002/nur.20076

Guzzetta CE. (1989). Effects of relaxation and music therapy on patients in a coronary care unit with presumptive acute myocardial infarction. Heart Lung, 18(6), 609-616.

Hosseini, S. E., Bagheri, M., \& Honarparvaran, N. (2013). Investigating the effect of music on labor pain and progress in the active stage of first labor. European Review for Medical and Pharmacological Sciences, 17(11), 1479-1487. http:// www.ncbi.nlm.nih.gov/pubmed/ 23894767

Joanna Briggs Institute. (2017). Critical Appraisal Checklist for Randomized Controlled Trials. The Joanna Briggs Institute. www.joannabriggs.org

Labrague, L. J., \& McEnroe-Petitte, D. M. (2016). Use of Music Intervention for Reducing Anxiety and Promoting Satisfaction in First-Time Filipino Fathers. American Journal of Men's Health, 10(2), 120-127. https://doi.org/ 10.1177/1557988314559240

Labrague, L. J., Rosales, R. A., Rosales, G. L., \& Fiel, G. B. (2013). Effects of soothing music on labor pain among Filipino mothers. Clinical Nursing Studies, 1(1). https://doi.org/10.5430/ cns.v1n1p35

Levett, K. M., Smith, C. A., Bensoussan, A., \& Dahlen, H. G. (2016). Complementary therapies for labour and birth study: a randomised controlled trial of antenatal integrative medicine for pain management in labour. BMJ Open, 6(7), e010691. https://doi.org/10.1136/ bmjopen-2015-010691

Llewellyn, D. \& Jones. (2001). Dasar-dasar Obstetri dan Ginekologi. Edisi IV. Jakarta : Hipokrates.

Liu, Y.-H., Chang, M.-Y., \& Chen, C.-H. (2010). Effects of music therapy on labour pain and anxiety in Taiwanese first-time mothers. Journal of Clinical Nursing, 19(7-8), 1065-1072. https:// doi.org/10.1111/j.13652702.2009.03028.x 
Efektivitas Music Therapy Terhadap Pengurangan Nyeri Persalinan...

Metgud, M., \& Gayathri, K. (2010). Effectiveness of Planned Teaching Program on Knowledge and Reducing Anxiety about Labor among Primigravidae in Selected Hospitals of Belgaum, Karnataka. Journal of South Asian Federation of Obstetrics and Gynaecology, 2(2), 163-168. https:// doi.org/10.5005/jp-journals-100061090

Miladinia, M., Pishgooie, A. H., Aliyari, S., \& Mousavi Nouri, E. (2017). The Comparison of the Effect of Two Complementary Medicine Methods (Music Therapy and Massage Therapy) On Postoperative Acute Pain After Abdominal Surgery: A Randomized Clinical Trial Study. Iranian Red Crescent Medical Journal, 19(6). https://doi.org/10.5812/ircmj. 14974

Ministério da Saúde. Secretaria de Ciência Tecnologia e Insumos Estratégicos. Departamento de Gestão e Incorporação de Tecnologias em Saúde. (2017). Diretrizes nacionais de assistência ao parto normal. Ministério da Saúde.

Moher, D., Liberati, A., Tetzlaff, J., \& Altman, D. G. (2009). Preferred Reporting Items for Systematic Reviews and Meta-Analyses: The PRISMA Statement. PLoS Medicine, 6(7), e1000097. https://doi.org/10.1371/ journal.pmed.1000097

Oyetunde, M. O., \& Ojerinde, O. E. (2013). Labour pain perception and use of non-pharmacologic labour support in newly delivered mothers in Ibadan, Nigeria. African Journal of Midwifery and Women's Health, 7(4), 164-169. https://doi.org/10.12968/ajmw. 2013.7.4.164

Rahman, S. A., Handayani, A., Sumarni, S., \& Mallongi, A. (2017). Penurunan Nyeri Persalinan dengan Kompres Hangat dan Massage Effleurage. Media Kesehatan Masyarakat Indonesia, 13(2), 147. https://doi.org/10.30597/ mkmi.v13i2.1986

Richards, T., Johnson, J., Sparks, A., \& Emerson, H. (2007). The effect of music therapy on patients' perception and manifestation of pain, anxiety, and patient satisfaction. Medsurg Nursing: Official Journal of the Academy of Medical-Surgical Nurses, 16(1), 7-14; quiz 15. http://www.ncbi.nlm.nih.gov/ pubmed/17441624

Sastrawinata, S. (2004). Ilmu Kesehatan Reproduksi : Obstetri Patolog. Ed. 2. Jakarta : EGC.

Simavli, S., Gumus, I., Kaygusuz, I., Yildirim, M., Usluogullari, B., \& Kafali, H. (2014). Effect of Music on Labor Pain Relief, Anxiety Level and Postpartum Analgesic Requirement: A Randomized Controlled Clinical Trial. Gynecologic and Obstetric Investigation, 78(4), 244-250. https:// doi.org/10.1159/000365085

Simavli, S., Kaygusuz, I., Gumus, I., Usluogulları, B., Yildirim, M., \& Kafali, H. (2014). Effect of music therapy during vaginal delivery on postpartum pain relief and mental health. Journal of Affective Disorders, 156, 194-199. https://doi.org/10.1016/ j.jad.2013.12.027

Solehati, T. (2018). Terapi Nonfarmakologi Nyeri Pada Persalinan: Systematic Review. Jurnal Keperawatan Muhammadiyah, 3(1). https://doi.org/ 10.30651/jkm.v3i1.1568

Taghavi, S., Barband, S., \& Khaki, A. (2015). Effect Of Hydrotherapy On Pain Of Labor Process. BALTICA, 28(1).

Taghinejad, H., Delpisheh, A., \& Suhrabi, Z. (2010). Comparison between Massage and Music Therapies to Relieve the Severity of Labor Pain. Women's Health, 6(3), 377-381. https:// doi.org/10.2217/WHE.10.15

Yuliatun, L. (2008). Penanganan Nyeri Persalinan dengan Metode Nonfarmakologi. Bayumedia Publishing. 